\title{
CPEC and Energy Rejuvenation: A Road to Improvement
}

\section{Fauzia Mubarik ${ }^{1}$, Javeria Shabbir ${ }^{2}$}

${ }^{1}$ Assistant Professor, National University of Modern Languages (NUML), Islamabad

${ }^{2}$ Lecturer, National University of Modern Languages (NUML), Islamabad

\section{A B S T R A C T}

This qualitative research study aims to investigate the role played by the established special economic zones under the program of the China-Pakistan Economic Corridor to improve and upgrade the energy sector in Pakistan. The key role of China under the Joined Cooperation Committee formed in 2013 has paved ways for Pakistan to bring profound stability in the energy crisis being faced by Pakistan which is also evident from its most recent investment of 33.45 billion Rupees under the CPEC mega energy project respectively. The availability of approximately 10,000 megawatts electricity to the National Grid of Pakistan in the year 2018 is near to its accomplishment phase. However, this accomplishment poses itself many challenges that may halter the smooth reviving of the energy and power crisis. The challenge of bridging the gap between the purchase prices of the electricity distribution companies (DISCOS) and the sales revenue generated as well as the inclusion of more hydropower projects because of them being less expensive than the wind power projects respectively.

Keywords: CPEC, Energy, DISCOS

\section{INTRODUCTION}

The millennium century is, by all means, the century of China that showed the world the unprecedented ability to rise. China has observed its growth in foreign countries through its established economic zones in different areas. This strategy to develop special economic zones has truly energized the economy of China by attracting heavy investment through the establishment of special economic zones(Bräutigam and Tang 2014). (Husain 2001) observes that only three decades ago the per day income of the 80-percentage population of the world was just the US \$1; however, by 1980-2000 China became the fastest growing economy with 9 percent real per capita income respectively. 
According to (Liu, Shi, et al. 2018), until now the concept of economic zones has not been standardized and different countries have different interpretations and names for economic zones such as the enterprise zone, the free zone, the foreign trade zone, the export processing zone, the special economic zone, the enterprise zone, and the export processing zone respectively. Nonetheless, the basic intention behind the development of the economic zones is viewed as a measure to the development of China entailing sustainable development both in the products and services sector ( $\mathrm{Hu}, 1998)$.

Pakistan is an economy where productive activities are restrained by its underdeveloped energy infrastructure. To improve the economic conditions of a country, raising living standards and eradicating poverty can be done with the help of improving the energy sector (Atmaca, \& Yigit, 2003). The development of economic zones in Pakistan with the support of China is a positive step towards the economic stability of Pakistan. There tend to be many added benefits such as better employment opportunities (Calabrese 2014) establishment of better infrastructure, agriculture, mineral, energy sector and tourist resorts (Hu 1998) respectively.

\subsection{The objective of the Study}

The aim of the present study is to theoretically and empirically investigate the role being played by the special economic zones built up by China under the CPEC project to help recover Pakistan from the energy crises. To build up the conclusion, the present study also tries to fill the gap by identifying other factors that may help in rejuvenating the energy crises in the case of Pakistan respectively.

\subsection{Significance of the Study}

The geostrategic position of Pakistan is playing a key role in world initiatives specifically of China's, as China is leveraging this to secure its energy supply, strengthening its economy and taking this step to transform itself into world economic power (Calabrese 2014). For decades, Pakistan and China are enjoying a multidimensional relationship and have further extended it by strengthening trade relationships, developing ways to invest in Pakistan and the exchange of technology transfer. This is evident from the free trade agreement signed by China and Pakistan that became effective from 2009 respectively. Despite these futuristic benefits, Pakistan still 
remains in the threshold of the prolonged crises of energy, trade deficit, circular debt, and power sector governance.

\subsection{The motivation of the Study}

Energy is the backbone of any country which lays the road map for any country's success. It has been observed worldwide that countries succeed when they have a sound energy policy. One vital part is when the country has contemporary technology to produce energy. According to (Atmaca and Yigit 2003) the global energy demand is expected to observe an increase of $41 \%$ from 2012 to 2035, with an annual average growth rate of $1.5 \%$ respectively.

In the case of Pakistan, there are 14 different units of energy entities; the four thermal power generation companies (GENCOs), one company managing the transmission of power (NTDC), and nine companies (DISCOs) which are electricity distribution companies. The main holding company of these units is Pepco respectively (see diagram 1).

Chart-1: Key Players in the Energy Sector

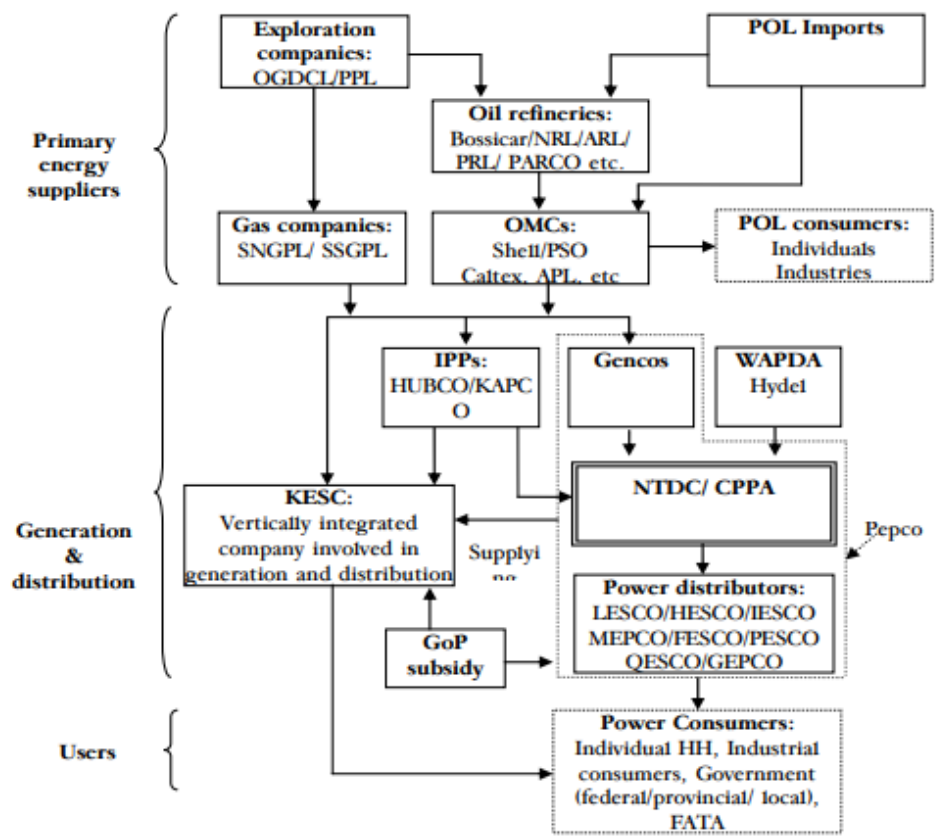

*Source: Dynamics of Circular Debt in Pakistan and Its Resolution,(Ali and Badar 2010) 
According to (Harijan, Uqaili, et al. 2008), the level of upgrading efforts needs to be doubled as only $55 \%$ of the population has access to electricity and only $18 \%$ of the population has access to gas in Pakistan and without electricity, economic development can't be materialized. In urban areas, the population uses UPS and generators to fill for power shortages for both power and gas generators for gas shortages. These means to fight power shortages and gas loads shedding have developed into many issues such as noise and air pollution and as a result, ban is afflicted on gas generators for consumers. Similarly, biofuels are utilized in Pakistan to substitute the energy shortage in most urban areas. Firewood, household wastes, and dung are used by $68 \%$ of the population which comprises the urban areas.

Fossil fuels are the major energy creating source in both developed and developing countries such as Pakistan, it is one of the most utilized forms of creating energy, however, is not in line with the sustainable development ideas. For sustainability, renewable energy sources are today's need and are identified as hydropower, solar, biomass, wind and geothermal and all these energy sources are cleaner sources as they emit almost zero emissions (Atmaca, \& Yigit, 2003). Due to their non-polluting in nature and other benefits such as they can't be monopolized with ease by a few countries such as the oil-producing countries respectively.

\subsection{Special Economic Zones (SEZs)}

A Special Economic Zone (SEZ) is a region that is secured to use for the growth of industries and to provide light tax policies and economic policies against general economic policies.

CPEC proposed the most essential development in the form of Special Economic Zones (SEZs) in the case of Pakistan. SEZ is a region which is actually secured according to the geographic limitations. Moreover, the investors and developers get the benefits and streamline processes that are established by the government. The governments of Pakistan and China seek to finish the Long Term Idea (LTP) of CPEC next to the success of the Early Harvest Program (EHP). There are three segments of LTP from which the processing of the first segment has already started as a path of success. Pakistan's economy and industries get the framework from SEZs as a result of the utilization of the 
strategic location of Pakistan.

The government of Pakistan has scheduled to form nine Special Economic Zones (SEZs) within four provinces under the three year period. For the development of infrastructure 5 SEZs are established by Pakistan. The three ranked SEZs to be accomplished in the first phase of LTP are M3 Industrial City in Faisalabad, Punjab, Chinese SEZ Dhabeji, Sindh and Hattar SEZ in KP province. Whereas, the remaining six sites include Rashakai Economic Zone, M-1 Nowshera, Bostan Industrial Zone District Pishin, Allama Iqbal Industrial City, Moqpondass SEZ in Gilgit-Baltistan, ICT Model Industrial Zone Islamabad, Growth of Industrial Park on Pakistan Steel Mills Land at Port Qasim near Karachi, respectively.

\subsection{Energy Crises and Circular Debt:}

PEPCO has cash flow problems that are connected to the circular debt in the energy sector. As PEPCO is the only unit of the energy sector, every issue regarding the Pepco cash flows is transferred to the other parts of the energy supply chain thereby giving rise to circular debt as shown in diagram 2. PEPCO pays the tariffs to suppliers (IPPs, OMCs, and gas companies) to purchase fuel and power, which it collects from customers for supplying electricity. It is important for PEPCO tariffs collection, that its inflows must be equal to outflows in order to function efficiently. However, as the inflows are uncertain and outflows are certain for their contractual nature, it is difficult to meet the outflows to inflows. It can simply be stated that PEPCO's cash flows are always uneven. PEPCO remains to control the all company's cash flows under its management as a result of the creation of CPPA (a move toward creating a single buyer purchasing power from IPPs and GENCOs and selling to DISCOs) by government, under the setup of PRPCO. The cost of power generation is high as compared to the end-customer tariffs, including the less government support to PEPCO under fiscal constraints. 


\section{Chart-2: Payment Flow in the Energy Sector}

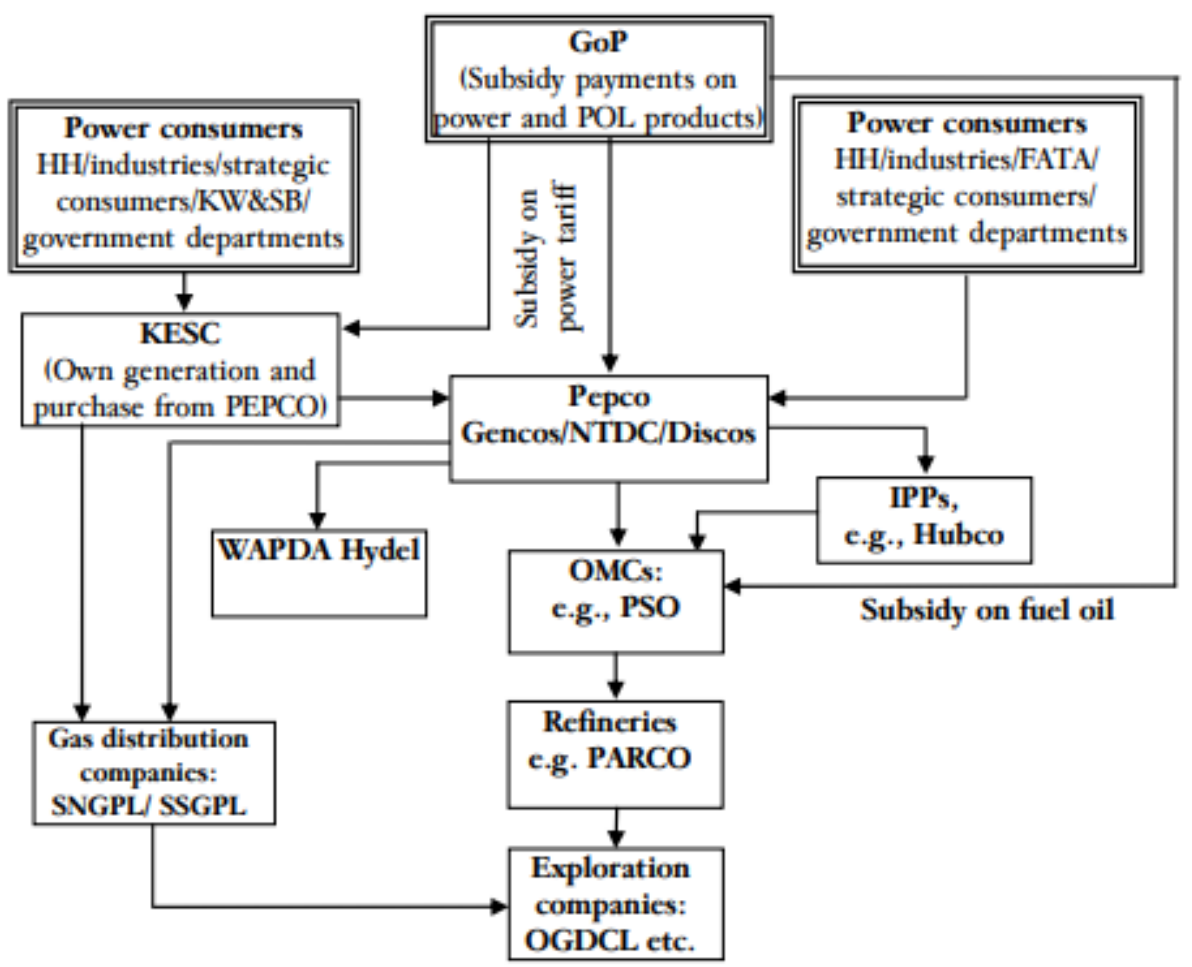

*Source: Dynamics of Circular Debt in Pakistan and Its Resolution, Ali and Badar (2010)

Another crucial problem being faced by PEPCO is the recovery of dues from its consumers. For example, the recovery of dues from FATA is very low. Similarly, a number of private individuals do not pay their monthly electricity bills. Also, number of departments in the federal and provincial governments has been delaying their payment of dues which is halting him smooth recovery of circular debt respectively.

\section{EMPIRICAL REVIEW}

The present study has also tried to incorporate the empirical researches carried out by the researchers to investigate the impact of the CPEC project on the energy sector improvement in case of Pakistan. According to the study conducted by (Kousar, Rehman et al. 2018) CPEC is a major development proven to be helpful in generating foreign direct investment, improving economic trade and growth, developing regional 
connectivity and in overcoming energy crises. Another study conducted by (Ali et. al., 2017) finds CPEC as a significant contributor in the job and business opportunities for Pakistan residents as well as to combat the current energy crises respectively.

(Chinedu, Daniel et al. 2019) have observed whether an economic growth is affected by energy consumption in Nigeria. By using Augmented Dickey Fuller Unit Root test statistic, Engle-Granger Co-integration test, the authors find that there is an impact of energy consumption in Nigeria. (Imran, Nawaz et al. 2019) have further investigated the mediating effect of project teamwork between transformational leadership and project success in Pakistan. After getting results from data consisting of 125 projects, authors conclude that project teamwork partially mediates the relationship among project success and leadership. (Halimanjaya 2019) identifies fiscal policy gaps caused in Indonesia's renewable energy sector and analyze political economy respectively. The study has used data from 37 stakeholders and data from Ministry of Finance, Ministry of Energy and Mineral resources. By using cluster approach and metasynthesis method and after analyzing results, the authors proposed that Indonesia has experienced problems referring with authority to manage electricity transmission respectively.

According to (Qureshi, Waqas et al. 2018) electricity distribution companies (DISCOs) obtain substantial electricity and sale it to users; also, they buy electricity under mutual sales contract with slight independent power producers (IPPs). The author discussed that Pakistan has provided several reasons to attract investors including foreign direct investment. The author tries to find the relationship between dependency on FDI and self-reliance on potential of indigenous entrepreneurs in wind power sector. By analyzing the drawn sample from wind power companies and projects, the author concludes that it is feasible to install wind power projects on self-reliance as compared to rely on FDI. However, indigenous entrepreneurs require policy framework which may lead to self-reliance and complete social and economic progress.

(Husain 2017) study that an addition of 10,000 MW of electricity to the National grid expects to be helpful in overcoming energy shortages. However, if the energy policies are not set right, there may be hostile consequences for liquidity and public 
finances including the worsen circular debts by failing to bridge the gap between sales revenues of Electricity distribution companies (DISCOs) and the purchase price of power. The author identify that this circular debt leads to the fiscal deficit unless DISCOs are either transferred or updated as commercial organizations free from political intrusion. Author also suggests that there is a need of Special Economic Zones (SEZs), industrial parks to be open for Pakistani firms on the same positions as to the Chinese. As studied by(Ali and Faisal 2017) Special Economies Zones (SEZs) development brings about efficiency in making of new policies, improved exports along with the foreign direct investment (FDI). Moreover, it may lead to the culture development of Research and development (R\&D) at corporate and industrial level. (Singh and Magray 2017) have further studied an effect of China-Pakistan Economic Corridor on Pakistani economy. The authors discussed the steps which could be taken to favor the scenario and cautions about the concerns of poorly managed implementation of the CPEC. Results show that CPEC proves to be an important project for both Pakistan and China. Also, the study shows that as CPEC is at very early stage, it is difficult to settle, at present, an actual impact of project on Pakistan economy.

(Jawaid and Waheed 2017) attempts to estimate regional trade and aggregate of Pakistan. The authors study the time series data from 1974 to 2014 respectively. The results obtained from fan chart suggest that there is much uncertainty related to the regional trade of Pakistan.

Similar studies from (Raza and Karim 2017), (Carbaugh 2004) suggest that in addition to economic issues, regional trade raise issues related to regional security and political contacts amid regional countries.

(Adil and bin Ab Hamid 2017) have studied the impact of leader member exchange on the relationship of individual feeling of energy and creative work involvement in Pakistan. The study has drawn sample of 300 manufacturing companies of Karachi. The authors conclude that leader member exchange has positive impact on relationship between individual feeling of energy and creative work involvement respectively.

(Ali, Mi et al. 2017) investigate the best set of CPEC energy significance projects 
to be accomplished in the first wave of development as well as the small and medium scale business and industry owners to select the finest obtainable alternative for attempting the energy shortfall. By using linear regression method, multi criteria decision making (AHP) and (TOPSIS); the authors suggest that while CPEC projects are in process of construction, solar panels are the best alternative for small scale businesses. Another study by (Abid and Ashfaq 2015) finds that CPEC expects to bring about prosperity in Pakistan in terms of transport link, energy crises, and establishment of infrastructure. Additionally, (Ali 2015) identify that China-Pakistan Economic Corridor (CPEC) is strategically important for China and Pakistan as it reflects that that project leads the China to an alternative route to safe its economic interest along with the regenerating the worsening economic conditions by adding a large investment in energy sector and development of infrastructure in Pakistan.

Ahmed \& Mi (2017) identifies the China-Pakistan Economic Corridor (CPEC) project as major initiative by Chinese Government, which believes to be supportive in social economic growth of Pakistan by increasing job opportunities, decreasing poverty level index, and improving and security and energy crises. However, authors also find challenges and threats that may impact on the development of project including instable political and economic condition of Pakistan, and instable security challenges to the related transit tariff concerns.(Hali, Iqbal et al. 2017) observe that Pakistan has faced huge electric power crises as a result of expensive fuels of generating electricity, shortage of political determination, inefficient management and diversion of country away from original source of electricity (Hydro power) to thermal power, which has damaged the country's economy. The author used GMM technique and mentioned that Pakistan, on its own is unable to fill the gap of required finances which are now being invested by China through China-Pakistan Economic Corridor (CPEC), which expects to increase electricity generation capacity. Moreover, authors suggest that Pakistan requires investing in technology and skills as compared to be completely dependent on China to invest in an Electricity Distribution Companies (DISCOs) and other electricity projects. Similarly, (Ali 2015) depicted that CPEC is not only a project rather it is a dominant road of improvement on Pakistan in terms of connectivity, railway sector and roads development. 
(Chaudhry, Gulzar et al. 2017) attempts to study the positive and negative outcomes of China-Pakistan Economic Corridor on Pakistan. By analyzing the data, collected from public opinion, authors imply that CPEC proves to be an essential project in improving energy crises, infrastructure development and connectivity. However, results also show that there may be negative impacts on Pakistan as unemployment as China brings their own labor force to the projects, medium and small industries may be acquired by Chinese.

(Bashir, Nasim et al. 2016) study the impact of electricity generation on Real GDP and Real Exports of Pakistan. The Results achieved from times series data conclude that electricity generation has a positive impact on Real GDP while it has a negative impact on Real Exports of Pakistan. (Polat, Uslu et al. 2011) have examined the relationship between real income, electricity consumption and employment in Turkey by using time series data. The authors find that there is no relationship between employment, electricity consumption and Real Income. Similarly, (Ashraf, Javid et al. 2013) observes the relationship between Electricity Consumption and Real GDP per capita in Pakistan. The authors used time series data and fine the long run relationship between Electricity Consumption and Real GDP also confirmed by (Raza, Shahbaz et al. 2015) that electricity consumption and GDP has bidirectional relationship.

(Sharif and Raza 2016) finds the relationship between carbon dioxide emission and urbanization in Pakistan. The authors collected annual time series data for the period of 1972 to 2013. Results obtained from Johansen and Juselius cointegration approach show that urbanization is the most contributing factor in affecting the level of carbon dioxide emission. (Javaid 2016) observes an impact of China-Pakistan Economic Corridor (CPEC) on Pakistani economy and concludes that CPEC proves to be a solution for serious energy shortages and fragile local regional connectivity infrastructures in Pakistan. Another study by (Hali, Iqbal et al. 2017), by comparing the historical capacity of energy, reveal that CPEC add 10,000 megawatt energy to National Grid of Pakistan which is the mega investment in an energy sector ever before. Study by (Miller 2017), it is indicated that the funding from China-Pakistan Economic Corridor (CPEC) leads towards the progress of private sectors of Pakistan, including transport and energy 
sectors. Moreover, this funding is also related with an enhanced number of Chinese stateowned enterprise sector and intergovernmental internal pressure to accept Chinese stateowned coverage for projects of energy.

(Hussain, Yuan et al. 2016) examine the significance of China-Pakistan Economic Corridor (CPEC) on Pakistan 's economy including the potential threats and challenges. By studying the past relationship between Pakistan and China, authors conclude that CPEC proposes a number of assistances to Pakistan by generating growth in real gross domestic product, improve energy crises, innovative infrastructure and developed business environment, moreover, authors find that CPEC success may face some threats by phases of political instability, unstable security conditions and the joint port construction of Chabahar by Iran and India in Pakistan. Similarly, (Nilofar, Jiang et al. 2014) in their study find that the current growth in Pak China Corridor leads the Pakistan the first transport center among the South Asian countries for the world's second largest economy. Moreover, as certain by China, private companies spend US $\$ 20$ billion in an energy sector.

(Singh, Jamasb et al. 2015) examine that through CPEC, regional economic cooperation with related regional moves can cover the way for cross border electricity and trade cooperation in connecting complementariness in electricity demand arrangement and gains from huge market access by eliminating trade restrictions between Pakistan, China, India and other related regions. According to (Small 2015) ChinaPakistan Economic Corridor (CPEC) is of high importance for Pakistan as well as for China as it allows China to increase its span of control over the countries. For Pakistan, CPEC proves to be helpful in solving economic, social and energy problems.

Another Study conducted by (Mustapha and Fagge 2015) investigated the relationship between economic growth and energy consumption by using Nigeria's data from 1908 to 2011. The study used the granger causality test and proposed that capital and labor have more impact on economic growth rather than energy consumption. According to(Roy, Ghosh et al. 2013) fiscal incentives play an important role in transition of energy however fiscal incentives and political economy aspects are uncertain and change rapidly which decreases the large investments in renewable energy sector 
projects in Indonesia. Similar studies conducted by (Bakhtyar, Sopian et al. 2013),(Dutu 2016), (Fathoni, Utama et al. 2014), (Nasruddin 2016) and (Winters and Cawvey 2015) does not discuss about fiscal incentives in Indonesia but highlights energy pricing policies. Moreover, these studies especially focus on geothermal energy.

In the respective research,(Enu and Havi 2014) examined the impact of electricity consumption on economic growth in Ghana. The authors used Augmented Dickey-Fuller test and find that electricity consumption has a positive effect on economic growth in short run while it has a negative impact on economic growth in long run.

(Onakoya, Onakoya et al. 2013) identify the relationship between Nigeria's economic growth and energy consumption for time period of 1975 to 2010. The authors used ordinary least square and co-integration techniques to analyze data and reveal that energy consumption and economic growth have a same movement. Authors further propose that electricity, aggregate energy consumption and petroleum have positive and significant impact on Nigeria's economic growth. Similar study conducted by (Ogundipe and Apata 2013) used Johansen and Juselius Co-integration technique to observe the relationship between economic growth and observe a significant bi-directional causal relationship between electricity consumption and economic growth.

\section{DISCUSSION ON FUTURE CHALLENGES OF CPEC}

The key role of China under the Joined Cooperation Committee formed in 2013 has paved ways for Pakistan to bring a profound stability in the energy crisis being faced by Pakistan which is also evident from its most recent investment of 33.45 billion Rupees under the CPEC mega energy project respectively. The availability of approximately 10,000 megawatts electricity to the National Grid of Pakistan in the year 2018 is near to its accomplishment phase. However, this accomplishment poses within itself many challenges that may halter the smooth reviving of the energy and power crisis. The challenge of bridging the gap between the purchase prices of the electricity distribution companies (DISCOS) and the sales revenue generated.

In an interview (Raza 2018) stressed on the renewable energy sources because these are the clean energy resources and unfortunately Pakistan despite having millions of 
megawatts of solar energy is not utilizing even 1\%. Most of the panels up to 1,300 megawatts are imported into the country but due to financial obligations, Pakistan is not manufacturing even $1 \%$ of solar panels. The state now has decided to undergo the joint ventures with several countries such as China, Korea and European countries to jointly utilize these resources respectively.

Circular debt issue still remains on due to the subsidization of power depletion. Moreover, the cost of budget of this subsidy does not get fiscal space by government. It becomes difficult for the government to totally eliminate the power subsidies due to the political concerns. Moreover, a choice of increasing tariffs may have consequences of declining revenue collection for PEPCO as the consumer is averse to pay their bills, and this tendency is certainly increasing. As the circular debt problem has worst impact on potential GDP therefore, there is a need to consider this issue as important. This is due to the reason that in an energy sector, there is liquidity constraints which have led to fall in generation of power.

The indirect cost of the subsidies makes the economy suffers until the power subsidies are sustained and get space in fiscal budget. As mentioned by (Rehman and Deyuan 2018), a corrupt management system is the basic reason of power crises in Pakistan. The distribution company's staff is involved in assisting theft against a large amount. Pakistan has nine public sector power distribution companies out of which Islamabad electric supply, Gujranwala and Faisalabad electric Supply companies perform best due to the on-time payment by customers and low stealing level. While the worst performed electric supply companies are of Peshawar, Quetta and Hyderabad with the high rate of stealing which is $40 \%$. There are the areas in Hyderabad where the bill collection is received by political parties and it is paid to Hyderabad Electric Supply Company (HESCO) a certain amount from what it collects. The HESCO was supported by USAID in 2013 with hundreds of kilometers of insulated cables in order to lessening of stealing but it did not become successful because of the less interest of staff of HESCO along with the local resistance to project staff in the areas where the cable was segregated.

The non-payments on part of the provinces and lingering issue of circular debt is 
the immediate hindrance in the smooth functioning of the special economic zones to overcome the crises of the power sector in case of Pakistan. The key factor that can control and monitor these troublesome issues is the power sector governance if it wants these zones to turn out to be the success.

\section{CONCLUSION AND POLICY IMPLICATION}

Industry development, promotion and growth are not possible without industry per capita growth. The commercial energy/electricity supply in Pakistan is identified residing in the lowest ranks globally in the country is one of the lowest in the world as according to (Harijan, Uqaili et al. 2008) respectively. In recent scenario, the economic shift has been observed in social, political and governmental level to find new ways to sustainable energy sources. Limited fossil fuels and their environmental concerns related to them are opening ways for renewal energy resources. Governments are trying to find the ways to exploit indigenous resources to rescue economy from the impeding slump and industry issues.

Some three decades ago, the energy mix of Pakistan was roughly 70 percent from hyderal resources and 30 percent from others. This proportion has almost reversed expensive energy mix is causing more problems for us. The high price of energy adversely affects the export competitiveness of country as it takes major share in the production cost. The business community will be much relieved if per unit price of electricity is brought down because that would make our products more competitive in international market.

According to (Hussain, Yuan et al. 2016), the CPEC comprises of the combination of projects with worth of $\$ 55$ billion out of which approximately $\$ 17.7$ billion will contribute excessively in the energy sector respectively.

With the fluctuation in fuel prices, there are other costs rises which are required to be passed on including cost increase under to consumers on quarterly basis. The implication of these quarterly adjustments is still incomplete. PEPCO needs to invest a large capital in addition to the strong enforcement in order to decrease the power theft.

In a nutshell, the economy of Pakistan is passing through the transformational 
phase and inclined to bring optimum transition in its key economic indicators such as infrastructure, recovery of debts, power sector shortages and the stability of Rupee under the threshold of the CPEC projects respectively.

\subsection{Future Direction of the Study}

The present study can also be extended to other CPEC projects to see their impact on the economy of Pakistan. In addition to the qualitative approach, the present study may also employ the meta-analysis approach for the quantitative analysis of the study respectively.

\section{REFERENCES}

Abid, M. and A. Ashfaq (2015). "CPEC: Challenges and opportunities for Pakistan." Journal of Pakistan Vision 16(2): 142-169.

Adil, M. S. and K. bin Ab Hamid (2017). "Impact of individual feelings of energy on creative work involvement: A mediating role of leader-member exchange." Journal of Management Sciences 4(1): 82-105.

Ali, A. (2015). "China Pakistan Economic Corridor (CPEC): Prospects and challenges for regional integeration." International Journal of Social Sciences and Humanity Studies 7(1): 1-15.

Ali, L., et al. (2017). "The potential socio-economic impact of china Pakistan economic corridor." Asian Development Policy Review 5(4): 191-198.

Ali, M. M. and F. Faisal (2017). "CPEC, SEZ (Special Economic Zones) and Entrepreneurial Development Prospects in Pakistan." Pakistan Development Review 56(4): 143-155.

Ali, S. S. and S. Badar (2010). "Dynamics of circular debt in Pakistan and its resolution."

Ashraf, Z., et al. (2013). "Electricity consumption and economic growth: evidence from Pakistan." Economics and Business Letters 2(1): 21-32.

Atmaca, I. and A. Yigit (2003). "Simulation of solar-powered absorption cooling system." Renewable Energy 28(8): 1277-1293.

Bakhtyar, B., et al. (2013). "Potentials and challenges in implementing feed-in tariff policy in Indonesia and the Philippines." Energy Policy 60: 418-423.

Bashir, F., et al. (2016). "Electricity generation and its impact on real GDP and real exports of Pakistan: A co-integration analysis." Journal of Management Sciences 3(1): 52-67.

Bräutigam, D. and X. Tang (2014). "'Going Global in Groups": Structural Transformation and China's Special Economic Zones Overseas." World Development 63: 78-91.

Calabrese, J. (2014). "Balancing on'the Fulcrum of Asia': China's Pakistan Strategy." Indian Journal of Asian Affairs 27(1/2): 1-20.

Carbaugh, R. J. (2004). "International Economics, Thomson Southern Western." Caves, Frankel and Jones (2002), World Trade and Payments 9.

Chaudhry, I. S., et al. (2017). "Impact of China-Pakistan Economic Corridor (CPEC) on Pakistan's trade: Empirical Evidence from Gravity Model." Review of Economics and Development Studies 3(1): 29-38.

Chinedu, U. A., et al. (2019). "Impact of Energy Consumption on Economic Growth in Nigeria: An Approach of Time Series Econometric Model." 
Dutu, R. (2016). "Challenges and policies in Indonesia's energy sector." Energy Policy 98: 513-519.

Enu, P. and E. Havi (2014). "Influence of electricity consumption on economic growth in ghana an econometric approach." International Journal of Economics, Commerce and Management 2(9): 1-20.

Fathoni, A. M., et al. (2014). "A technical and economic potential of solar energy application with feed-in tariff policy in Indonesia." Procedia Environmental Sciences 20: 89-96.

Hali, S. M., et al. (2017). "Impact of energy sources and the electricity crisis on the economic growth: Policy implications for pakistan." Journal of Energy Tech. and Policy 7(2).

Halimanjaya, A. (2019). "The Political Economy of Indonesia's Renewable Energy Sector and Its Fiscal Policy Gap." International Journal of Economics, Finance and Management Sciences 7(2): 45.

Harijan, K., et al. (2008). Renewable energy for managing energy crisis in Pakistan. International Multi Topic Conference, Springer.

Hu, Z. (1998). "The appraisal of seven economic zones in China." Chinese Geographical Science 8(4): 326-334.

Husain, I. (2001). "Economic ties between China and Pakistan." Pakistan Horizon 54(3): 17-21.

Husain, I. (2017). Policy imperatives for CPEC, Dawn.

Hussain, J., et al. (2016). "China Pakistan economic corridor." Defence Journal 19(6): 13.

Imran, S. M. J. I., et al. (2019). "Does Project Teamwork Matter? Investigating the Relationship between Transformational Leadership and Project Success." Journal of Management Sciences 6(1): 79-95.

Javaid, U. (2016). "Assessing CPEC: Potential threats and prospects." Journal of the Research Society of Pakistan 53(2).

Jawaid, S. T. and A. Waheed (2017). "Uncertainty and risk analysis of Pakistan's regional trade: Fan chart approach." Journal of Management Sciences 4(1): 55-81.

Kousar, S., et al. (2018). "China-Pakistan Economic Corridor: a gateway to sustainable economic development." International Journal of Social Economics 45(6): 909924.

Liu, W., et al. (2018). "The Development Evaluation of Economic Zones in China." International journal of environmental research and public health 15(1): 56.

Miller, D. T. (2017). "The China Pakistan Economic Corridor: Indicator of Chinese strategic energy goals and a challenge to the open procurement status quo." Jackson School of International Studies. University of Washington, Seattle Washington, web. isanet. org/Web/.../HKU2017-s/.../a30ae7f2-83ba-4b48-b15c3ebbe670d948. pdf (25.12. 2018).

Mustapha, A. M. and A. M. Fagge (2015). "Energy Consumption and Economic Growth in Nigeria: A Causality Analysis." Journal of Economics and Sustainable Development 6(13).

Nasruddin, M. (2016). "Idrus Alhamid, Y. Daud, A. Surachman, A. Sugiyono, HB Aditya, and TMI Mahlia." Renewable and Sustainable Energy Reviews 53: 733-740.

Nilofar, M., et al. (2014). "The growing economic ties between Pakistan and china and its impact on the economy of Pakistan." IMPACT: International Journal of Research in Humanities, Arts and Literature 2(12): 49-54. 
Ogundipe, A. A. and A. Apata (2013). "Electricity consumption and economic growth in Nigeria." Journal of Business Management and Applied Economics 11(4).

Onakoya, A. B., et al. (2013). "Energy consumption and Nigerian economic growth: An empirical analysis." European scientific journal 9(4).

Polat, Ö., et al. (2011). "The Relationship Among Electricity Consumption." Employment and Real Income in Turkey, Suleyman Demirel University The Journal of Faculty of Economics and Administrative Sciences 16(1): 349-362.

Qureshi, J. A., et al. (2018). "Saying 'No'to Foreign Direct Investment in Wind Power Generation Sector by Attracting Indigenous Entrepreneurs: A Step towards Selfreliance." International Journal of Economics and Financial Issues 8(3): 284.

Raza, S. A. and M. Z. A. Karim (2017). "Influence of systemic banking crisis and currency crisis on the relationship of export and economic growth: Evidence from China." Journal of Chinese Economic and Foreign Trade Studies 10(1): 82-110.

Raza, S. A., et al. (2015). "Energy conservation policies, growth and trade performance: Evidence of feedback hypothesis in Pakistan." Energy Policy 80: 1-10.

Rehman, A. and Z. Deyuan (2018). "Pakistan's energy scenario: a forecast of commercial energy consumption and supply from different sources through 2030." Energy, Sustainability and Society 8(1): 26.

Roy, J., et al. (2013). "Fiscal instruments: crucial role in financing low carbon transition in energy systems." Current Opinion in Environmental Sustainability 5(2): 261-269.

Sharif, A. and S. A. Raza (2016). "Dynamic relationship between urbanization, energy consumption and environmental degradation in Pakistan: Evidence from structure break testing." Journal of Management Sciences 3(1): 1-21.

Singh, A., et al. (2015). Cross-border electricity cooperation in South Asia, The World Bank.

Singh, S. and J. M. Magray (2017). "China-Pakistan Economic Corridor (CPEC), Its Impacts On Pakistan Economy." International Journal of Innovative Research and Advanced Studies.

Small, A. (2015). "China-Pakistan: A strategic relationship in the shadows." Yale Global Online.

Winters, M. S. and M. Cawvey (2015). "Governance obstacles to geothermal energy development in Indonesia." Journal of Current Southeast Asian Affairs 34(1): 2756. 